\title{
The Implementation of Elementary Student Character Values among the Bajo Tribe through Pancasila Values as Character Building
}

\author{
Farid Wajdi ${ }^{1}$, Zulfikar Putra²
}

Program Studi PPKn FKIP Universitas Sembilanbelas November, Kolaka, Indonesia ${ }^{1,2}$ wajdikf83@usn.ac.id', zulfikarputra2016@gmail.com²

\section{Article History}

accepted 24/03/2021

\begin{abstract}
The purpose of this study was to determine the implementation of the character values of the Bajo tribe through the values of Pancasila as reinforcing character building in Bajo ethnic children, elementary school students. This type of qualitative research uses an ethnographic approach accompanied by data collection techniques through observation, interviews, and documentation. The data analysis technique in this study used the Spradley model. The findings of the research show that elementary school students on Masudu Island, most of whom have native Bajo ethnic backgrounds, have religious values, independence, discipline, social care, national spirit, mutual cooperation, and responsibility, as the implementation of Pancasila values and in accordance with character values. a nation that is seen in the daily lives of the children of the Bajo tribe who participate in studying at school, even though the school is located on one of the islands (in the sea).
\end{abstract}

Keywords: Bajo tribe, Pancasila values, character building

\begin{abstract}
Abstrak
Tujuan penelitian ini adalah untuk mengetahui implementasi nilai karakter suku Bajo melalui nilai-nilai pancasila sebagai penguat character building pada anak-anak suku Bajo siswa sekolah dasar. Jenis penelitian kualitatif dengan pendekatan etnografi disertai teknik pengumpulan data melalui pengamatan, wawancara, dan dokumentasi. Teknik analisis data dalam penelitian ini menggunakan model Spradley. Temuan hasil penelitian, bahwa siswa SD di Pulau Masudu yang sebagian besar berlatar belakang asli suku Bajo terdapat nilai religius, mandiri, disiplin, peduli sosial, semangat kebangsaan, gotong royong, dan tanggung jawab, sebagai implementasi nilai-nilai pancasila dan bersesuaian dengan nilai karakter bangsa yang terlihat dalam kehidupan keseharian anak-anak suku Bajo yang berpartisipasi dalam menuntut ilmu di sekolah, walaupun letak sekolah berada di salah satu pulau (di laut).
\end{abstract}

Kata kunci: suku Bajo, nilai-nilai pancasila, character building

Social, Humanities, and Education Studies (SHEs): Conference Series https://jurnal.uns.ac.id/shes

p-ISSN 2620-9284

e-ISSN 2620-9292 


\section{PENDAHULUAN}

Pancasila merupakan landasan ideologi kebangsaan negara republik Indonesia. Indonesia sebagai negara majemuk akan budaya, suku (etnis), bahasa, dan agama, mampu mempertahankan kedaulatan negara kesatuan republik Indonesia dengan falsafah kebangsaan, yakni Pancasila sebagai sebuah ideologi kewarganegaraan Indonesia (Z. Putra 2021). Kearifan lokal suku budaya yang ada di Indonesia masing-masing memiliki ciri khas (nilai karakter) yang terbentuk dalam kehidupannya. Nilai karakter tersebut merupakan fondasi perilaku bagi setiap individu maupun kelompok suku bangsa. Suku Bajo dikenal sebagai suku laut dan merupakan salah satu suku bangsa yang juga hidup dalam wilayah negara kesatuan republik Indonesia (NKRI), memiliki ciri khas (nilai karakter) sebagai bagian kearifan lokal budaya mereka. Nilai-nilai pendidikan karakter etnis Bajo terbentuk dengan adanya interaksi sosial terhadap alam laut yang merupakan tempat dan sumber kehidupan sejak para pendahulunya hidup berpindah-pindah (sea nomads) dari satu pulau ke pulau lainnya (Wajdi 2020). Suku Bajo yang sudah hidup bertahun-tahun di lautan dengan cara mengembara dari satu pulau ke pulau yang lain dalam mencari sumber kehidupan keluarga, bahkan hingga pulau mancanegara tidak bisa melepaskan habitatnya (kebiasaan hidup) sebagai suku laut. Rencana relokasi pemerintah setempat bagi komunitas masyarakat suku Bajo untuk bisa hidup membaur dengan masyarakat umum di daratan senantiasa tidak membuahkan hasil. Seperti halnya, komunitas masyarakat suku Bajo yang ada Kabupaten Bombana tepatnya di Pulau Masudu, sebagian besar dari mereka tidak menginginkan hidup menetap dari laut menuju pesisir maupun daratan dan suku Bajo dikenal juga sebagai masyarakat yang kurang pendidikannya. Namun, Semangat para orang tua yang masih hidup di laut dengan adanya perubahan dan perkembangan zaman tidak melemahkan niatan mereka untuk tetap menyekolahkan anak-anaknya, dengan harapan kehidupan keluarga bisa menjadi lebih baik.

Berdasarkan uraian tersebut, maka penelitian ini memfokuskan bagaimana para siswa sekolah dasar kalangan suku bajo dalam mengimplementasikan nilai karakter melalui nilai-nilai pancasila sebagai penguat character building.

Teori

Kehidupan komunitas etnis Bajo tidak bisa terlepas dari sumber kehidupan laut dan dikenal sebagai manusia laut yang tangguh dan handal, serta memiliki kekayaan nilai budaya dan kearifan lokal. Bangsa Indonesia adalah bangsa yang kaya akan ajaran dan nilai luhur yang dimiliki setiap budaya lokal yang ada dipenjuru nusantara Indonesia (Wajdi 2020). Bangsa Indonesia adalah bangsa yang bersifat pluralistik, sehingga membutuhkan suatu pedoman yang dapat dijadikan sebagai prinsip dalam hidup bermasyarakat, berbangsa, dan bernegara yang mampu mengikat seluruh komponen bangsa yang pluralistik tersebut agar tidak terjerumus ke dalam perpecahan (Risladiba 2018).

Indonesia sebagai negara berkembang senantiasa berupaya menghadapi dan bersaing terhadap tantangan-tantangan guna menuju negara Indonesia yang maju. Hal tersebut diperkuat dengan adanya nilai-nilai moral yang terdapat pada budaya, agama, dan nilai karakter bangsa, yaitu nilai-nilai pancasila sebagai ideologi dan jati diri (falsafah) bangsa. Era disrupsi memunculkan nilai-nilai yang menghantarkan pada perubahan pola pikir, pola sikap dan pola tindak serta tatanan hidup, dinamika masyarakat/warga negara yang semakin cepat mengakses informasi positif maupun negatif yang tak pelak membentuk opini. Sehingga, jika tidak segera disikapi dengan bijak, akan semakin menjauhkan nilai-nilai Pancasila dalam kehidupan bermasyarakat, berbangsa dan bernegara (Z. Putra 2021). Nilai-nilai yang terkandung dalam Pancasila merupakan solusi dari permasalahan yang dihadapi negara ini (Ajeng Lara Sati, Marhamah, Nurhot 2021). Dewasa ini, pemerintah terus menggencarkan pentingnya pendidikan karakter, pendidikan pancasila, dan kearifan lokal budaya bangsa. 
Penanaman dan pembentukan nilai-nilai pancasila pada semua peserta didik senantiasa diterapkan dan dikaji mulai dari pendidikan dasar hingga perguruan tinggi.

Penguatan pendidikan karakter sebagai nawacita pemerintah, pintu masuk pembenahan pendidikan nasional dan revolusi karakter bangsa (Kemdikbud 2017). Pendidikan Pancasila merupakan proses pendidikan dalam menanamkan ideologi atau pandangan hidup bangsa berdasarkan butir-butir yang terkandung dalam nilai-nilai pancasila baik dalam kehidupan bermasyarakat, berbangsa, dan bernegara (Z. Putra 2021). Pendidikan yang beralaskan garis-hidup dari bangsanya (cultureel-nationaal) dan ditujukan untuk keperluan peri-kehidupan (maatschappelijk) yang dapat mengangkat derajat negara dan rakyatnya, agar dapat bekerja bersama-sama dengan lain-lain bangsa untuk kemuliaan segenap manusia di seluruh dunia (K. H. Dewantara 2013b). Pendidikan sebagai sarana manajemen dalam pembentukan perkembangan pribadi manusia berperan penting dalam menghadapi situasi dan kondisi kehidupan. Dengan pendidikan, seseorang mampu mengelola, menjalani, menghadapi, dan mengatasi permasalahan kehidupannya (Wajdi 2021b). Character building sebagai langkah dan upaya dalam proses pembentukan pribadi peserta didik dalam suatu bangsa didasari oleh nilai-nilai moral yang terdapat dalam nilai budaya, nilai agama, dan nilai bangsa. Dengan demikian, nilai-nilai pacasila sebagai kristalisasi nilai budaya dan agama bangsa Indonesia menjadi rujukan penguatan character building negara Indonesia yang multikultural sebagai tujuan dan fungsi pendidikan nasional.

Mengembangkan kemampuan dan membentuk watak serta peradaban bangsa yang bermartabat merupakan fungsi pendidikan nasional. Bangsa yang bermartabat artinya bangsa yang bertujuan untuk berkembangnya potensi peserta didik agar menjadi manusia yang beriman dan bertakwa kepada Tuhan Yang Maha Esa, berakhlak mulia, sehat, berilmu, cakap, kreatif, mandiri, dan menjadi warga negara yang demokratis serta bertanggungjawab (Tarmizi 2020). Penelitian yang relevan dengan penelitian ini diantaranya, yaitu: hasil penelitian (Risladiba 2018), berjudul "Supporting and Investigation Factors of Dayak Community Hindu Budha Earth as In Implementing Values of Pancasila", menyimpulkan bahwa faktor pendukung dalam mengimplementasikan nilai-nilai Pancasila adalah adanya tradisi-tradisi yang dilaksanakan oleh masyarakat Dayak Losarang yang di dalamnya terkandung nilainilai. Dan hasil penelitian (Ajeng Lara Sati, Marhamah, Nurhot 2021), berjudul "representasi nilai pancasila dalam kehidupan berbudaya", menyimpulkan bahwa menjalankan sosial budaya berarti telah mengamalkan nilai-nilai Pancasila. Sebagai warga negara Indonesia, kita semua diberi amanah untuk menerapkan nilai-nilai Pancasila terutama bersifat sosial dan budaya melalui pemeliharaan toleransi terhadap orang lain dan prioritaskan kepentingan dan kesejahteraan bersama

\section{METODE}

Jenis penelitian yang digunakan dalam penelitian ini adalah kualitatif dengan pendekatan etnografi melalui teknik analisis data model Spradley dengan melakukan langkah-langkah analisis domain, analisis taksonomi, analisis komponensial, dan analisis tema kultural (Spradley 1979). Etnografi digunakan untuk penelitian dibanyak bidang, salah satunya bidang pendidikan yang berfokus pada lingkungan sekitar sistem budaya seperti masyarakat, kelompok, sistem, organisasi dan semacamnya. Genre ini studi tentang perilaku, norma, kepercayaan, kebiasaan, nilai, pola manusia terapan dan fenomena manusia seperti yang diungkapkan dalam praktik (Shagrir 2017). Tujuan penelitian etnografi adalah mendeskripsikan, menganalisis, dan menginterpretasikan kebudayaan suatu kelompok, termasuk didalamnya keyakinan, perilaku, dan bahasa yang digunakan kelompok tersebut (A Ramly, F Wajdi 2020). Dengan demikian, pendekatan etnografi dalam penelitian ini sangat relevan menganalisis nilai karakter siswa SD dari kalangan asli suku Bajo melalui nilai pancasila sebagai penguat character building. 
HASIL DAN PEMBAHASAN

Hasil penelitian implementasi nilai karakter siswa SD kalangan suku Bajo melalui nilai-nilai pancasila sebagai penguat character building dapat dilihat pada hasil analisis data melalui model Spradley. Analisis data dalam penelitian ini dilakukan pada siswa SD kalangan suku Bajo yang berpartisipasi dan melaksanakan pendidikan di sekolah dasar di Pulau Masudu. Analisis melalui pendekatan etnografi model Spradley dilakukan dengan empat tahapan analisis, yaitu analisis domain, analisis taksonomi, analisis komponensial, dan analisis tema. Berikut penjelasan hasil penelitian berdasarkan analisis model Spradley.

\section{Analisis Domain}

Perilaku (nilai karakter) siswa SD Terapung di Pulau Masudu terlihat ketika pelaksanaan pembelajaran di sekolah menurut waktu yang telah ditentukan. Nilai karakter tersebut terpola pada setiap individu berdasarkan interaksi sosial dan ajaran yang telah terbentuk sejak usia dini dalam keseharian hidup komunitas suku Bajo. Ajaran suku Bajo, ketika hendak melaut mereka senantiasa tak lupa melakukan ritual (do'a) dengan harapan keselamatan dan memperoleh hasil laut bekal hidup keluarga yang dapat dikonsumsi maupun dijual kepada masyarakat umum di daratan. Keberanian dan kemandirian terlihat pada pribadi suku Bajo yang sumber kehidupannya diperoleh dari hasil melaut dan didasari waktu-waktu yang diperbolehkan dalam mencari sumber kehidupan di laut. Rasa kebersamaan dalam mencari sumber kehidupan dan membangun sebuah permukiman di laut maupun mempersiapkan peralatan melaut merupakan komitmen suku Bajo dalam kehidupan yang aman, nyaman, dan damai. Hal tersebut merupakan rasa tanggung jawab yang dibangun sejak kehidupan para pendahulu suku Bajo. Adapun analisis domain penelitian ini digambarkan dalam tabel sebagai berikut:

Tabel 1. Analisis Domain

\begin{tabular}{|c|c|c|}
\hline Rincian Domain (X) & $\begin{array}{l}\text { Hubungan } \\
\text { Semantik }\end{array}$ & $\begin{array}{l}\text { Rincian Domain } \\
\text { (Y) }\end{array}$ \\
\hline $\begin{array}{l}\text { - Melakukan ritual adat, baik ketika pergi } \\
\text { dan pulang melaut, maupun dalam acara } \\
\text { ungkapan syukur atas hasil perolehan } \\
\text { dari laut. } \\
\text { - Pergi melaut pada waktu yang telah } \\
\text { menjadi adat suku Bajo (waktu yang } \\
\text { diperbolehkan dan waktu yang dilarang } \\
\text { serta tempat yang diperbolehkan maupun } \\
\text { yang dilarang). } \\
\text { - Mempersiapkan peralatan melaut yang } \\
\text { dibuat dengan bahan-bahan alami } \\
\text { (perahu dan alat tangkap). } \\
\text { - Menerima suku lain yang ingin tinggal } \\
\text { dan hidup bersama dalam komunitas } \\
\text { suku Bajo, bekerja mencari sumber } \\
\text { kehidupan dalam memenuhi kebutuhan } \\
\text { hidup sehari-hari dan membiayai sekolah } \\
\text { anak-anaknya. } \\
\text { - Membangun permukiman dan memenuhi } \\
\text { kebutuhan hidup bagi keluarga dan } \\
\text { komunitas suku Bajo dengan senantiasa } \\
\text { dilakukan secara bersama-sama. }\end{array}$ & Jenis & $\begin{array}{c}\text { Perilaku yang } \\
\text { mencirikan nilai } \\
\text { karakter suku Bajo. }\end{array}$ \\
\hline $\begin{array}{l}\text { - Siswa dilatih untuk selalu mencium } \\
\text { tangan orang tua ketika hendak pergi ke }\end{array}$ & Jenis & $\begin{array}{l}\text { Perilaku siswa SD } \\
\text { suku Bajo dalam }\end{array}$ \\
\hline
\end{tabular}


sekolah, mengucapkan salam dan berdo'a; Mencium tangan guru sekolah, memberi salam kepada semua (baik guru maupun teman di sekolah) dan membaca do'a di awal pembelajaran. Hal-hal tersebut juga dilakukan ketika selesai pembelajaran.

- Siswa dilatih untuk selalu pergi ke sekolah pada jam yang sesuai ditentukan.

- Siswa dilatih untuk selalu mempersiapkan pakaian dan peralatan sekolah, serta menyelesaikan PR.

- Siswa dilatih untuk selalu berusaha belajar demi meraih prestasi.

- Siswa dilatih untuk selalu membantu teman yang belum memahami pelajaran dengan kegiatan belajar kelompok, belajar dan bermain bersama ketika ada siswa yang berlainan suku di sekolah.

- Siswa dilatih untuk selalu berusaha menyelesaikan tugas belajar di kelas dan tugas di rumah.

- Nilai Ketuhanan (siswa beribadah/berdo'a sesuai dengan agama dan kepercayaan yang dianutnya).

- Nilai Kemanusiaan (siswa belajar dan bermain bersama baik sesama suku Bajo maupun yang bukan dari suku Bajo).

- Nilai Persatuan (siswa menjaga warisan budaya suku dengan menggunakan bahasa Bajo sehari-hari, melakukan yang diajarkan orang tua, dan berteman baik kepada siswa yang berbeda suku, agama, dan bahasa).

- Nilai Kerakyatan (ketika siswa ada perselisihan paham langsung orang tua dan guru terlibat mengatasi hal tersebut).

- Nilai Keadilan (melaksanakan tugas yang diberikan guru di kelas maupun di rumah dan bersikap saling menghormati).

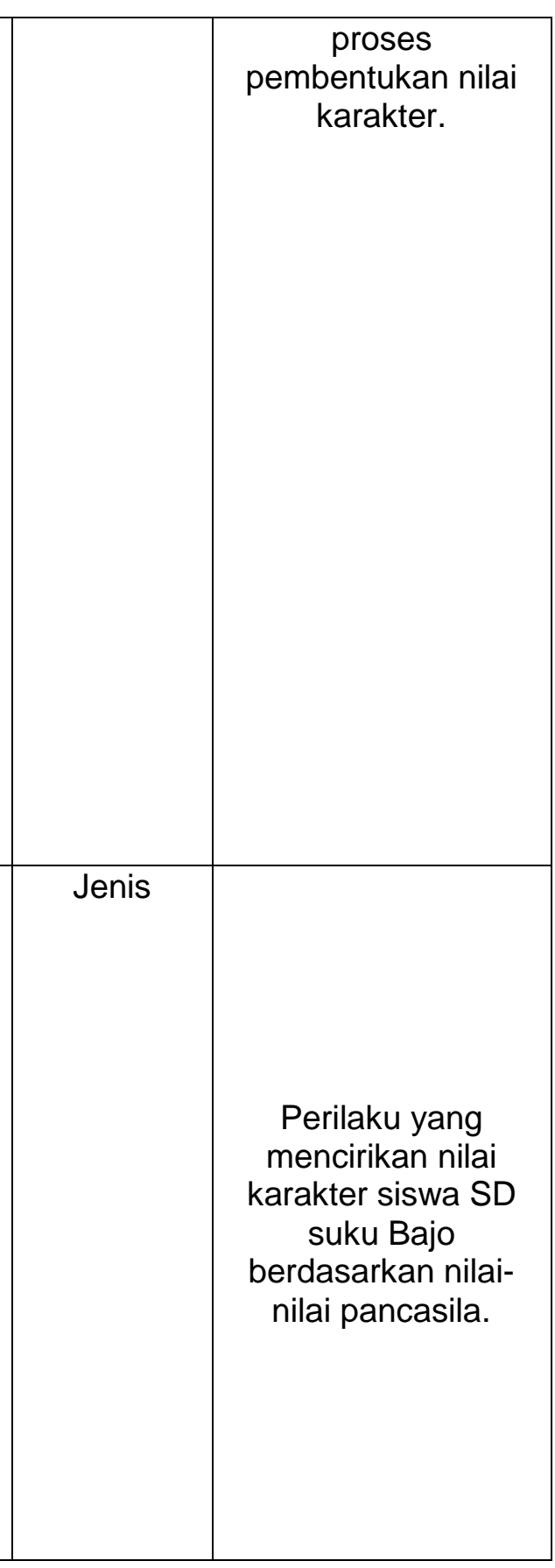

Berdasarkan tabel tersebut di atas, maka hasil kegiatan pengamatan dan wawancara siswa suku Bajo di Pulau Masudu menggambarkan nilai karakter siswa SD Terapung yang memiliki nilai karakter yang terbentuk akibat interaksi sosial dan ajaran para pendahulu suku Bajo. Dengan ikut berpartisipasinya anak-anak suku Bajo dalam proses pembelajaran di sekolah nilai karakter tersebut diperkuat dengan nilai-nilai pancasila sebagai penguat character building, yaitu beribadah/berdo'a sesuai dengan agama dan kepercayaan yang dianutnya (nilai ketuhanan); belajar dan bermain bersama baik sesama suku Bajo maupun yang bukan dari suku Bajo (nilai kemanusiaan); menjaga warisan budaya suku dengan menggunakan bahasa Bajo sehari-hari, melakukan yang diajarkan orang tua, dan berteman baik kepada siswa yang berbeda suku, agama, dan bahasa (nilai persatuan); perselisihan paham langsung orang tua dan guru terlibat mengatasi hal tersebut (nilai kerakyatan); ketika 
siswa ada perselisihan paham langsung orang tua dan guru terlibat mengatasi hal tersebut; dan melaksanakan tugas yang diberikan guru di kelas maupun di rumah dan bersikap saling menghormati (nilai keadilan).

\section{Analisis Taksonomi}

Tahapan analisis taksonomi dilakukan penyelidikan domain telah dipilih. Domain terpilih dipaparkan dengan jelas nilai karakter siswa suku Bajo melalui nilai pancasila sebagai penguat character building. Domain-domain yang telah dijelaskan pada tabel sebelumnya dipilih dan didalami melalui analisis taksonomi nilai karakter siswa SD yang telah diajarkan dalam lingkungan keluarga dan masyarakat suku Bajo diperkuat melalui nilai pancasila sebagai penguat character building di sekolah menunjukkan perkembangan yang signifikan. Berikut gambaran domain yang dipilih melalui analisis sebelumnya.

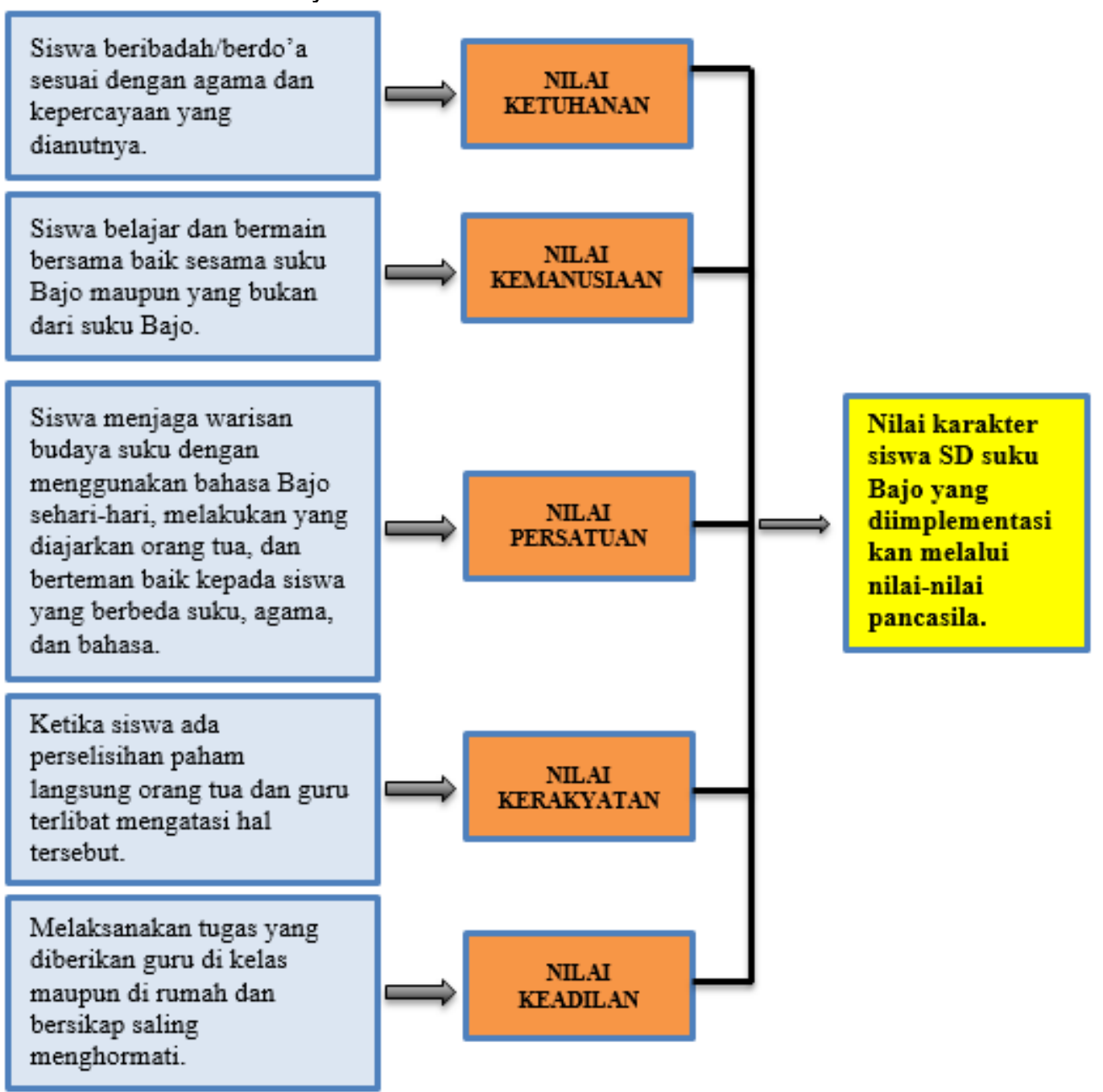

Bagan 1. Analisis Taksonomi

Berdasarkan bagan tersebut di atas, maka nilai karakter siswa SD suku Bajo yang diajarkan dan dilaksanakan dalam kehidupan sehari-hari dalam lingkungan keluarga dan masyarakatnya menjadi kuat dalam proses pembentukan dan perkembangan karakternya dengan mempelajari dan menjalankan nilai-nilai pancasila di sekolah sebagai penguat character building. Hal tersebut dapat terwujud dengan adanya tripusat pendidikan, yaitu pendidikan keluarga, masyarakat, dan sekolah.

\section{Analisis Komponensial}

Karakter siswa SD suku Bajo pada tahapan komponensial terlihat dari hasil pembentukan karakter yang telah diajarkan orang tua, sehingga anak-anak mereka 
perlahan mengikuti ajaran orang tua berdasarkan ajaran baik budaya dan agama yang dianutnya. Dengan ikut berpartisipasinya anak-anak suku Bajo tersebut di sekolah, maka pembentukan karakter siswa SD suku Bajo terlaksana dalam lingkungan keluarga, masyarakat, dan diperkuat pembentukan karakter di sekolah melalui nilainilai pancasila. Adapun analisi komponensial dapat dijelaskan dalam tabel sebagai berikut:

\begin{tabular}{|c|c|c|}
\hline Nilai Karakter Siswa & $\begin{array}{c}\text { Character } \\
\text { Building }\end{array}$ & $\begin{array}{l}\text { Nilai-nilai } \\
\text { Pancasila }\end{array}$ \\
\hline $\begin{array}{l}\text { Siswa dilatih untuk selalu mencium tangan orang } \\
\text { tua ketika hendak pergi ke sekolah, mengucapkan } \\
\text { salam dan berdo'a; Mencium tangan guru } \\
\text { sekolah, memberi salam kepada semua (baik } \\
\text { guru maupun teman di sekolah) dan membaca } \\
\text { do'a di awal pembelajaran. Hal-hal tersebut juga } \\
\text { dilakukan ketika selesai pembelajaran. }\end{array}$ & Religius; & $\begin{array}{c}\text { Nilai } \\
\text { Ketuhanan }\end{array}$ \\
\hline $\begin{array}{l}\text { Siswa dilatih untuk selalu mempersiapkan } \\
\text { pakaian dan peralatan sekolah, serta } \\
\text { menyelesaikan PR. Siswa dilatih untuk selalu } \\
\text { berusaha belajar demi meraih prestasi. Siswa } \\
\text { dilatih untuk selalu pergi ke sekolah pada jam } \\
\text { yang sesuai ditentukan. }\end{array}$ & $\begin{array}{l}\text { Mandiri; } \\
\text { Disiplin; }\end{array}$ & $\begin{array}{c}\text { Nilai } \\
\underset{n}{\text { Kemanusiaa }}\end{array}$ \\
\hline $\begin{array}{l}\text { Siswa dilatih untuk selalu membantu teman yang } \\
\text { belum memahami pelajaran dengan kegiatan } \\
\text { belajar kelompok, belajar dan bermain bersama } \\
\text { ketika ada siswa yang berlainan suku di sekolah. }\end{array}$ & $\begin{array}{l}\text { Peduli } \\
\text { Sosial; }\end{array}$ & $\begin{array}{c}\text { Nilai } \\
\text { Persatuan }\end{array}$ \\
\hline $\begin{array}{l}\text { Siswa dilatih untuk selalu membantu teman yang } \\
\text { belum memahami pelajaran dengan kegiatan } \\
\text { belajar kelompok, belajar dan bermain bersama } \\
\text { ketika ada siswa yang berlainan suku di sekolah. }\end{array}$ & $\begin{array}{l}\text { Semangat } \\
\text { Kebangsaan } \\
\text {; Gotong } \\
\text { Royong; }\end{array}$ & $\begin{array}{c}\text { Nilai } \\
\text { Kerakyatan }\end{array}$ \\
\hline $\begin{array}{l}\text { Siswa dilatih untuk selalu berusaha } \\
\text { menyelesaikan tugas belajar di kelas dan tugas di } \\
\text { rumah. }\end{array}$ & $\begin{array}{l}\text { Tanggung } \\
\text { Jawab }\end{array}$ & Nilai Keadilan \\
\hline
\end{tabular}

Tabel 2. Analisis Komponensial

Berdasarkan tabel tersebut di atas, maka nilai karakter siswa SD suku Bajo akan menjadi kuat dengan adanya penanaman dan pembentukan pola karakter melalui nilai-nilai pancasila yang diperankan siswa antara nilai karakter lingkungan budaya suku dengan lingkungan budaya sekolah.

\section{Analisis Tema}

Berdasarkan analisis domain, analisis taksonomi, dan analisis komponensial, maka nilai karakter siswa SD suku Bajo memiliki ciki perilaku yang diajarkan para orang tua melalui ajaran para pendahulu mereka dalam lingkungan keluarga dan masyarakat. Nilai-nilai karakter siswa tersebut diperkuat dengan nilai-nilai pancasila sebagai nilai karakter kebangsaan negara Indonesia melalui pembentukan karakter (character building) pada budaya lingkungan sekolah. Dengan demikian, tripusat pendidikan menjadi landasan dalam mengimplementasikan nilai-nilai karakter melalui nilai pancasila sebagai penguat character building jika hal tersebut senantiasa dilaksanakan dengan baik oleh peran guru di sekolah dan peran orang tua serta masyarakat dalam kehidupan sehari-harinya.

\section{Pembahasan}

Berdasarkan hasil penelitian, maka nilai-nilai karakter seperti itu dapat ditumbuhkan pada setiap manusia sejak dini sebagai fondasi untuk kehidupan warga 
negara. Sebagai mana telah dijelaskan diatas bahwa pendidikan karakter sangat erat kaitannya dengan kehidupan kemudian dalam implementasinya tidak dapat hanya sebatas diajarkan, tetapi harus dilakukan dalam bentuk pembiasaan, pemahaman, keteladanan, dan aplikasi yang terus menerus, hingga akhirnya ditemukan makna dari suatu nilai karakter (Muhtar 2014). Secara kultural, pembangunan karakter bangsa merupakan suatu keharusan dari suatu bangsa yang multicultural (Ariandy 2019). Pengembangan budaya dan karakter bangsa hanya dapat dilakukan dalam suatu proses pendidikan yang tidak melepaskan peserta didik dari lingkungan sosial, budaya masyarakat, dan budaya bangsa, yaitu Pancasila, jadi pendidikan budaya dan karakter bangsa haruslah berdasarkan nilai-nilai Pancasila (Muhtar 2014).

Pancasila sebagai sumber nilai dalam kehidupan bermasyarakat, berbangsa, dan bernegara bagi bangsa Indonesia, dasar moral atau norma dan sebagai tolak ukur baik buruk dan benar salahnya sikap, perubahan dan tingkah laku sebagai bangsa Indonesia (Z. Putra 2021). Pancasila merupakan ideologi negara yang telah disepakati sebagai dasar dalam penyelenggaraan kehidupan bermasyarakat, berbangsa, dan bernegara. Pengamalan nilai-nilai pancasila tentunya akan membawa pada perkembangan kehidupan masyarakat yang berketuhanan, berperikemanusiaan, bersatu, berkerakyatan, dan berkeadilan (Nurhadianto 2016). Pancasila sebagai filsafat bangsa dan negara Republik Indonesia mengandung makna setiap aspek kehidupan dalam hal kebangsaan, kenegaraan dan kemasyarakatan harus didasarkan pada nilainilai ketuhanan, kemanusiaan, persatuan, kerakyatan, dan yang terakhir keadilan (A. W. Dewantara 2017). Dengan demikian, pancasila merupakan kumpulan nilai kebaikan berupa nilai-nilai norma dan etika. Dan dalam menanamkan nilai-nilai tersebut, pendidikan sebagai wadah pembentukan nilai-nilai karakter sebagai ciri pribadi individu maupun masyarakat sebagai kunci tripusat pendidikan.

Pendidikan adalah daya upaya untuk memajukan bertumbuhnya budi pekerti (kekuatan batin, karakter), pikiran (intellect) dan tubuh anak. Bagianbagian itu tidak boleh dipisahkan agar kita dapat memajukan kesempurnaan hidup anak kita $(\mathrm{K} . \mathrm{H}$. Dewantara 2013a). Pendidikan merupakan faktor utama dalam pembentukan kepribadian manusia. Pendidikan memiliki fungsi strategis dalam membentuk baik atau buruknya kepribadian manusia menurut ukuran normatif (Ahmad Saekhu HM 2020). Pendidikan, selain sebagai sarana transfer ilmu pengetahuan, sosial budaya, juga merupakan sarana untuk mewariskan ideologi bangsa kepada generasi selanjutnya yang sekali lagi hanya dapat dilakukan melalui pendidikan. Suatu bangsa akan menjadi kuat dengan sistem pendidikannya yang kuat dan baik kualitasnya (Sutono 2015). Pendidikan adalah proses pembimbingan, pengarahan, dan pengalaman yang ditransfer kepada setiap individu melalui peranan orangtua, guru, masyarakat, lingkungan, budaya, dan negara (Wajdi 2020). Tahapan implementasi character building, yaitu pengalaman belajar dan proses belajar mengajar yang arahnya pada pembentukan nilai-nilai karakter yang dilakukan dalam tiga lingkungan, yaitu pendidikan formal (sekolah), in-formal (keluarga) dan non-formal (masyarakat) ( $\mathrm{J}$ Jasrudin, Z Putera 2020). Pendidikan sebagai upaya menumbuhkembangkan pengetahuan, karakter dan keterampilan peserta didik agar menjadi generasi muda yang siap dan mampu menghadapi segala tantangan yang menyangkut perubahan sosial dalam kehidupan masyarakat (Ahmadi, Haris, and Akbal 2020). Pendidikan sekurang-kurangnya memiliki empat fungsi, yaitu transfer ilmu, konservasi dan pengembangan ilmu, penguasaan life skill dan teknologi, serta membangun karakter (character building) (Putra 2018). Pembelajaran merupakan sebuah proses perubahan tingkah laku dalam interaksi proses pembelajaran antara pendidik dan peserta didik guna membentuk dan mengembangkan cara berpikir peserta didik dalam meningkatkan serta mengkonstruksikan pengetahuan baru yang diperoleh peserta didik (Wajdi 2021a). 
Berdasarkan uraian tersebut, maka character building (pembentukan karakter) melalui implementasi nilai-nilai pancasila pada anak siswa SD kalangan suku Bajo dapat dilaksanakan dalam lingkungan sekolah dan kelas.

\section{SIMPULAN}

Berdasarkan hasil dan pembahasan penelitian, maka implementasi nilai karakter siswa SD kalangan suku Bajo melalui nilai-nilai pancasila sebagai penguat character building terlihat pada nilai karakter siswa SD yang terbentuk dalam lingkungan keluarga dan masyarakat sekitar sebagai nilai budaya mereka. Dengan ikut berpartisipasinya anak-anak suku Bajo di sekolah, guru menanamkan dan membentuk karakter mereka melalui nilai-nilai pancasila. Dengan demikian, pelaksanaan nilai karakter siswa melalui nilai-nilai pancasila menjadi kuat sebagai pola pembentukan karakter mereka. Sehingga, terdapat nilai religius, mandiri, disiplin, peduli sosial, semangat kebangsaan, gotong royong, dan tanggung jawab dalam diri siswa SD suku Bajo.

\section{DAFTAR PUSTAKA}

A Ramly, F Wajdi, Z Putera. 2020. "Nilai-Nilai Pendidikan Karakter Dalam Pelaksanaan Kabasano Kampanaha." Jurnal Pendidikan Kewarganegaraan 10 (2): 69-79. https://doi.org/10.20527/kewarganegaraan.v10i2.9339.

Ahmad Saekhu HM, Yuda Prihatono. 2020. "Buku Kendali Sebagai Media Implementasi Menguatkan Pendidikan Karakter." Metodik Didaktik 15 (2): 1-12.

Ahmadi, Muhammad Zul, Hasnawi Haris, and Muhammad Akbal. 2020. "Implementasi Program Penguatan Pendidikan Karakter Di Sekolah." Phinisi Integration Review 3 (2): 305. https://doi.org/10.26858/pir.v3i2.14971.

Ajeng Lara Sati, Marhamah, Nurhot, Ullia Dewi. 2021. "Representasi Nilai Pancasila Dalam Kehidupan Berbudaya." Jurnal Syntax Fusion 1 (2): 6.

Ariandy, M. 2019. "Kebijakan Kurikulum Dan Dinamika Penguatan Pendidikan Karakter Di Indonesia." Sukma: Jurnal Pendidikan 3 (2): 137-68.

Dewantara, Agustinus. W. 2017. Diskursus Filsafat Pancasila Dewasa Ini. Yogyakarta: Kanisius.

Dewantara, Ki Hadjar. 2013a. Ki Hadjar Dewantara: Pendidikan Pemikiran, Konsepsi, Keteladanan, Sikap Merdeka I (Pendidikan). Yogyakarta: Majelis Luhur Persatuan Tamansiswa.

Dewantara, Ki Hadjar. 2013b. Ki Hadjar Dewantara: Pendidikan Pemikiran, Konsepsi, Keteladanan, Sikap Merdeka II (Kebudayaan). Yogyakarta: Majelis Luhur Persatuan Tamansiswa.

J Jasrudin, Z Putera, F Wajdi. 2020. "Membangun Karakter Peserta Didik Melalui Penguatan Kompetensi PKn Dan Penerapan Alternatif Pendekatan Pembelajaran." Jurnal Pendidikan Kewarganegaraan 10 (2): 42-52. https://doi.org/10.20527/kewarganegaraan.v10i2.8629.

Kemdikbud, Pengelola Web. 2017. "Penguatan Pendidikan Karakter Jadi Pintu Masuk Pembenahan Pendidikan Nasional." Biro Komunikasi Dan Layanan Masyarakat Kemdikbud Dan Tim Komunikasi Pemerintah Kominfo. 2017. https://www.kemdikbud.go.id/main/blog/2017/07/penguatan-pendidikankarakter-jadi-pintu-masuk-pembenahan-pendidikan-nasional.

Muhtar, Tatang. 2014. "Analisis Kurikulum 2013 Ditinjau Dari Aspek Nilai Karakter Bangsa." Mimbar Sekolah Dasar 1 (2): 168-75. https://doi.org/10.17509/mimbar-sd.v1i2.879.

Nurhadianto, Nurhadianto. 2016. "Internalisasi Nilai-Nilai Pancasila Dalam Upaya Membentuk Pelajar Anti Narkoba." Jurnal Pendidikan IImu Sosial 23 (2): 44. https://doi.org/10.17509/jpis.v23i2.1618.

Putra, Zulfikar. 2018. "Implementasi Pendidikan Pancasila Sebagai Character Building 
Mahasiswa Di Universitas Sembilanbelas November Kolaka." Jurnal Citizenship: Media Publikasi Pendidikan Pancasila Dan Kewarganegaraan 1 (1): 9-13.

Risladiba, Dadang Sundawa. 2018. "Supporting And Investigation Factors of Dayak Community Hindu Budha Earth as In Implementing Values of Pancasila." Journal of National Awareness Civil Society 4 (1): 1-16.

Shagrir, Leah. 2017. Journey to Ethnographic Research. Pringer International Publishing.

Spradley, J. P. 1979. The Ethnographic Interview. New York: Holt, Rhinehart \& Winston.

Sutono, Agus. 2015. "Meneguhkan Pancasila Sebagai Filsafat Pendidikan Nasional." Jurnal IImiah Civis 5 (1): 666-78. http://journal.upgris.ac.id/index.php/civis/article/view/628.

Tarmizi. 2020. "Meningkatkan Pemahaman Nilai-Nilai Pancasila Dengan Pembelajaran Kooperatif Metode STAD Pada Siswa SMA Negeri 6 Kaur Bengkulu." Attractive: Innovative Education Journal 2 (2): 1-13.

Wajdi, Farid. 2021a. Buku Ajar Perencanaan Pengajaran Panduan Di Perguruan Tinggi. Malang: Ahlimedia Press.

Wajdi, Farid. 2020. Nilai-Nilai Karakter Etnis Bajo Relevan Dengan Nilai Karakter Bangsa. Makassar: Yayasan Barcode.

2021b. "Manajemen Perkembangan Siswa SD Melalui Peran Guru Dan Orang Tua Pada Masa Pandemi." JAMP: Jurnal Adminitrasi Dan Manajemen Pendidikan 4 (1): 41-50. http://journal2.um.ac.id/index.php/jamp/article/view/17229.

Z. Putra, F. Wajdi. 2021. Buku Ajar Pendidikan Pancasila Dan Kewarganegaraan Panduan Kuliah Di Perguruan Tinggi. Malang: Ahlimedia Press. 